\title{
THERMAL SENSATION IN THE BLADDER
}

\author{
BY
}

\section{P. W. NATHAN}

From the Neurological Research Unit of the Medical Research Council, the National Hospital, Queen Square, London

It has been pointed out in an earlier paper by Nathan and Smith (1951) that "it is not yet definitely known whether the bladder mucosa is sensitive to thermal stimuli ". As a review of the literature has shown that there is no generally accepted opinion on the presence or absence of such sensation, the present investigation was undertaken.

Guyon (1887) stated that one could feel in the bladder definitely whether liquids were hot or cold. Von Frankl-Hochwart and Zuckerkandl (1906) wrote that " the delicate sensitivity of the bladder to thermal stimuli is well known ". Zimmermann (1909) investigated the sensation by means of passing a urethral catheter on himself and running through it into the bladder fluids at temperatures of $0^{\circ} \mathrm{C}$. and $50^{\circ} \mathrm{C}$; ; he found that temperature was appreciated in the distal 2 to $3 \mathrm{~cm}$. of the male urethra, but nowhere more proximally in the urethra, nor in the bladder. Müller (1919) reported that one of his colleagues, who investigated thermal sensation on his own bladder, found no sensation evoked by temperatures as different as $0^{\circ} \mathrm{C}$. and $45^{\circ}$ C. Waltz (1922), using a double-walled, glass urethral catheter, to avoid thermally stimulating the urethra, came to the conclusion that the bladder is insensitive to thermal stimulation. He also applied menthol to the mucosa; this caused no sensation, whereas, when it is applied to the skin, it stimulates cold spots, causing a sensation of cold. Moore (1924) investigated bladder sensation by passing " knobbed applicators" along the urethra ; the sensitivity to thermal stimuli was examined by passing through a cystoscope such an instrument, consisting in this case of a glass tip $2 \mathrm{~cm}$. by $4 \mathrm{~mm}$. on a steel wire, which had previously been immersed in water at $60^{\circ} \mathrm{C}$. and $15^{\circ} \mathrm{C}$. He concluded that " heat was perceptible in every instance in the normal bladders . . . Cold was not as readily detected as heat ". Dees and Langworthy (1935) expressed the opinion that there is " a crude recognition of temperature in the mucosa"; and Lang- worthy, Kolb, and Lewis (1940) held the view that the bladder mucosa is "slightly responsive to heat, cold, and touch". McLellan (1939) stated : "Thermal sensory nerve endings are present and the patient is generally aware of heat or cold and variations in the temperature. . . . The bladder differs from other abdominal viscera in that it has the presence of thermal and tactile sensory endings ". McLellan and Goodell (1943) later investigated thermal sensation by permitting fluid to pass into the bladder through a urethral catheter; they found that fluid at $45^{\circ} \mathrm{C}$. was felt to be hot, and fluid at $0^{\circ} \mathrm{C}$. " very cool ". Band (1950) stated : "The bladder wall can distinguish between the hot and cold lotion employed for lavage".

As nearly all investigators passed liquids at various temperatures into the bladder through the urethra, it is possible that the disagreement concerning the observations may have arisen from neglecting the fact that the urethra is sensitive to thermal stimuli. As stimuli applied to the bladder are usually referred to the urethra, it is easy to see that the subjects being investigated might have been able to tell the temperature of the liquids, without being able to tell whether they experienced the sensation in the bladder or the urethra. This criticism applies least to Moore and Waltz, but they reported opposite findings.

\section{Material and Methods}

A method of dealing with this problem was required that permitted the direct application of liquids at various temperatures to the bladder, avoiding thermal stimulation of the urethra. Accordingly, patients having suprapubic cystostomies were investigated. It was, incidentally, difficult to find enough suitable patients for such an investigation. For the main source of such material, patients having prostatectomy, is not very satisfactory; the reasons for this are that this operation is nowadays usually performed in one stage, and that such patients are usually old and 
not necessarily vigilant and scrupulous observers. Patients with disorders of the nervous system causing disorders of micturition cannot be used for an investigation of sensation. Again, many patients with suprapubic cystostomies cannot be used, as the stoma leaks, permitting the fluid to reach tissues known to be sensitive to thermal stimulation. The most suitable are those who have had the cystostomy made about a week previously, as the stitches are still in the abdominal wall, preventing leakage, and cystitis is minimal.

Fifteen patients were examined. The bladder was emptied, and then fluid of known temperatures was allowed to flow into it through the suprapubic tube. During the next minute or two, the patient was asked to say what he felt, and if he made no comment on thermal sensation, direct questions were put to him. The bladder was emptied, and refilled with fluid at another temperature. The temperature of the first fluid to be run in was either in the neighbourhood of $45^{\circ} \mathrm{C}$., or of $15^{\circ} \mathrm{C}$.; the succeeding irrigation was at the opposite end of the scale, so that the stimuli applied were maximally contrasted. The limits of the temperatures used were $49^{\circ}-15^{\circ} \mathrm{C}$.; about four different temperatures were applied to each patient. The patient was encouraged to compare each irrigation with the previous one.

\section{Results}

None of the patients gave any satisfactory evidence of possessing thermal sensation in the bladder.

Typical comments of one patient were as follows : $21^{\circ} \mathrm{C}$.: slight pricking, no thermal sensation; $42^{\circ}$ C.: slight pricking, no thermal sensation ; $21^{\circ} \mathrm{C}$.: no thermal sensation; then (after he had been persuaded to try and feel some thermal sensation) " probably warmer than the last one".

One of the 15 patients, who had previously had the prostate removed, experienced a sensation only when a hot fluid was employed : fluids at $18^{\circ} \mathrm{C}$. or $37^{\circ} \mathrm{C}$. gave rise to no sensation, but fluids at $45^{\circ} \mathrm{C}$. and $48^{\circ} \mathrm{C}$. were both felt as "definitely warm"; this sensation was not immediate but delayed.

Three other cases, not included in the above 15 , are relevant. One patient, with carcinoma of the cervix, having normal bladder function and no involvement of the bladder by growth, had no thermal sensation in the bladder or urethra. When fluid was passed into the bladder per urethram she could not tell its temperature. Thus fluids at $44^{\circ} \mathrm{C}$. and $16^{\circ} \mathrm{C}$. were called warm, while fluids at $25^{\circ} \mathrm{C}$. and $28^{\circ} \mathrm{C}$. caused no sensation. Another patient, suffering from motor neuron disease, had very poor urethral thermal sensation; his bladder was filled through a urethral catheter. He experienced no sensation with temperatures of $37^{\circ} \mathrm{C}$. or $24^{\circ} \mathrm{C}$.; $44^{\circ} \mathrm{C}$. felt warm in the penis, but "caused no sensation inside". One other patient, attending hospital on account of a urethral caruncle, stated, when fluid at $25^{\circ} \mathrm{C}$. was run into her bladder through a urethral catheter, that it felt cold in the urethra and warm in the bladder.

\section{Conclusion}

The human bladder is insensitive to thermal stimuli.

I should like to thank Mr. Norman Matheson, Mr. Harland Rees, and Mr. W. L. F. Utley for allowing me to investigate cases under their care; and Dr. E. A. Carmichael for his useful advice.

\section{REFERENCES}

Band, D. (1950). VIIIe Congr. Soc. int. Urologia, Barcelona, 1949 Vol. 2, p. 224. Paris.

Dees, J. E., and Langworthy, O. R. (1935). J. Urol., Baltimore, 34,359 .

Frankl-Hochwart, L. von, and Zuckerkandl, O. (1906). Die nervösen Erkrankungen der Harnblase, 2nd ed. Vienna.

Guyon, F. (1887). Ann. Mal. Org. gén.-urin., 5, 193.

Langworthy, O. R., Kolb, L. C., and Lewis, L. G. (1940). Physiology of Micturition. Baltimore.

McLellan, F. C. (1939). The Neurogenic Bladder. Springfie!d, Illinois.

McLellan, A. M., and Goodell, H. (1943). "Pain". Res. Pubi. Ass. nerv. ment. Dis., 23, 252.

Moore, T. D. (1924). Arch. Surg., Chicago, 9, 176.

Müller, L. R. (1919). Dtsch. Arch. klin. Med., 128, 81.

Nathan, P. W., and Smith, M. C. (1951). Journal of Neurology, Neurosurgery and Psychiatry, 14, 262

Waltz, W. (1922). Dtsch. Z. Nervenheilk., 74, 278

Zimmermann, R. (1909). Mitt. Grenzgeb. Med. Chir., 20, 445. 